\title{
Effect of pad water flow rate on evaporative cooling system efficiency in laying hen housing
}

\author{
Mohamed Saied Ghoname \\ Agricultural Engineering Department, Faculty of Agriculture, Tanta University, Egypt
}

\begin{abstract}
An experiment was conducted in three commercial laying hen houses with 32-week-old hens in the summer of 2017 in a commercial farm in Gharbia Province, Egypt $\left(31.06^{\circ} \mathrm{N}, 31.16^{\circ} \mathrm{E}\right)$ using an evaporative pad cooling system to determine the most suitable water flow rate for maintaining indoor air temperature within the thermal comfort zone. The experiment was conducted using three different water flow rates, i.e. $4.76,5.65$, and $6.35 \mathrm{~L} \mathrm{~min}^{-1} \cdot \mathrm{m}^{-2}$, to assess the effect of different water flow rates on evaporative pad cooling system performance and determine the most suitable water flow rate for maintaining the thermal comfort zone of laying hens. The evaporative pad cooling system maintained the mean indoor air temperature below $28^{\circ} \mathrm{C}$. The mean indoor air relative humidity during the experimental period ranged from 72.6 to $73.8 \%$. The $4.76 \mathrm{~L} \mathrm{~min}{ }^{-1} \cdot \mathrm{m}^{-2}$ water flow rate resulted in the highest saturation efficiency (ca. 73.75\%). In contrast, the $6.35 \mathrm{~L} \mathrm{~min}^{-1} \mathrm{~m}^{-2}$ water flow rate resulted in the lowest saturation efficiency $(70.63 \%)$. The mean cooling energy values were $69.11,66.0$, and $66.65 \mathrm{kwh}$ for water flow rates of $4.76,5.56$, and $6.35 \mathrm{Lmin}^{-1} \mathrm{~m}^{-2}$, respectively. The highest temperature-humidity index was $27.78^{\circ} \mathrm{C}$, which indicated that birds were not stressed in all treatments.
\end{abstract}

\section{Introduction}

Poultry is a good source of cheap protein compared with other types of animal proteins. Poultry production includes both the production of eggs from laying hens and meat from broilers. Eggs are considered one of the most important natural sources of protein

\footnotetext{
Correspondence: Mohamed Saied Ghoname, Agricultural Engineering Department, Faculty of Agriculture, Tanta University, Egypt.

E-mail: mohamed.ghonaim@agr.tanta.edu.eg;

ghoname_mohamed@ymail.com
}

Key words: Evaporative cooling; flow rate; laying hens; pad; water.

Received for publication: 20 January 2020

Accepted for publication: 10 September 2020.

${ }^{(}$Copyright: the Author(s), 2020

Licensee PAGEPress, Italy

Journal of Agricultural Engineering 2020; LI:1051

doi:10.4081/jae.2020.1051

This article is distributed under the terms of the Creative Commons Attribution Noncommercial License (by-nc 4.0) which permits any noncommercial use, distribution, and reproduction in any medium, provided the original author(s) and source are credited. for consumption as well as for use with other ingredients in food production. In 2018, the total Egyptian national egg production in 2018 was $8,794,335,000$ eggs, which is equivalent to 454250 tonnes (FAO, 2020).

Heat stress can occur when the dry-bulb temperature and indoor relative humidity are excessive. Indoor relative humidity should range between 50 to $70 \%$ for broilers up to 21 days of age and 40 to $60 \%$ afterwards (Fairchild, 2012). Heat stress decreases the amount of heat released from the body, increasing the core body temperature of birds. Increasing core body temperature by $4^{\circ} \mathrm{C}$ can lead to death. Increasing indoor air temperature over $28^{\circ} \mathrm{C}$ is the main cause for a decrease in the feed intake of laying hens. Egg weight and laying rate decrease by approximately $1.5 \%$ and $0.3 \mathrm{~g}$, respectively, when the indoor air temperature increases by $1{ }^{\circ} \mathrm{C}$ (You, 2005). Star et al. (2009) reported a reduction of $31.6 \%$ in feed conversion, $36.4 \%$ in egg production, and $3.41 \%$ in egg weight in laying hens exposed to heat stress $\left(32^{\circ} \mathrm{C}\right)$ at 24 weeks of age for 22 consecutive days. Heat stress arises from the interaction between air temperature, humidity, radiant heat, and air speed, and air temperature plays a major role. The optimal indoor air temperature for production performance is between $19-22^{\circ} \mathrm{C}$ for laying hens (Charles, 2002). In another study (Ebeid et al., 2012), heat stress caused a significant reduction in egg weight $(-3.24 \%)$, eggshell thickness $(-1.2 \%)$, eggshell weight $(-9.93 \%)$, and eggshell percentage $(-0.66 \%)$.

Heat stress results from a negative balance between the net amount of energy flowing from the animal to its surrounding environment and the amount of heat energy produced by the animal. This imbalance is induced by changes in several environmental factors (e.g., sunlight, thermal radiation, and air temperature), animal properties (e.g., rate of metabolism and moisture loss), and thermoregulatory mechanisms, such as conduction, radiation, convection, and evaporation. When the bird's ability to dissipate heat during heat stress is compromised, excessive heat production can potentially be life-threatening and affect live weight, feed efficiency, egg production, egg quality, egg shell quality, fertility, hatchability, and survival. Among several environmental factors that affect layer chicken production, heat stress has the most pronounced effect on production parameters, especially given that birds are sensitive to heat waves, because of their feathers and lack of sweat glands, thus making heat dissipation particularly difficult (Estrada-Pareja et al., 2007).

The ideal ambient air temperature in bird housing for laying hens is approximately $25^{\circ} \mathrm{C}$ (Xin, 2011). In agricultural structures, evaporative pad cooling systems are an important method for reducing heat stress. Evaporative pad cooling systems aim to reduce the dry inlet temperature, but they increase relative humidity. The reduction in dry-bulb temperature is driven by the extraction of heat from dry air by evaporation.

Evaporation is achieved by both heat and air velocity to promote the release of water from pad surfaces. Many parameters can decrease or increase the efficiency of pad evaporative cooling sys- 
tems. These parameters can be classified into two categories. The first category pertains to environmental conditions, including outside air temperature and relative humidity. The second category refers to the specifications of the system, including pad thickness, pad face air velocity, pad material, and water flow rate above the pad. Pad evaporative cooling represents the direct evaporative cooling based on mechanical and thermal contact between air and water (Porumb et al., 2016).

The water flow rate through the pad evaporative cooling system is one of the most important parameters affecting the saturation efficiency of the system. Below, the importance of pad evaporative cooling is clarified, as many researchers have concluded that the water flow rate has no significant effects on the performance of evaporative cooling systems.

Gunhan et al. (2007) evaluated the effects of the water flow rate on the evaporative saturation efficiency of pad materials in an air conditioning chamber of $3 \times 3 \times 6 \mathrm{~m}$ in size. They found that there was no significant effect of the water flow rate $(1.00,1.25,1.50$, and $1.75 \mathrm{~L} \mathrm{~min}^{-1}$ ) on this chamber. In contrast, other studies found that the water flow rate is critically important for evaporative pad cooling systems (Dzivama et al., 1999) and generally indicated that saturation efficiency increases as the water flow rate increases until the pad is sufficiently moist. Nelson (2006) suggested that the optimal water flow rate passing through the cooling pads is $7.5 \mathrm{~L} \mathrm{~min}^{-1}$ per length unit of cooling pads. The length of cooling pads in the experiment was $9.6 \mathrm{~m}$; therefore, $7.2 \mathrm{~L} \mathrm{~min}^{-1}$ per length unit of cooling pads was the optimal water flow rate. The saturation efficiency of the evaporative cooling system based on a fanpad system under different circumstances was studied during the hottest days of the summer season (June to August of 2014). ANSI and ASABE (ANSI/ASABE, 2008; ASABE, 2008) recommended airspeed values and minimum water flows for four different types of pads. Aspen fibre pads of 50 and $100 \mathrm{~mm}$ thickness mounted vertically should be operated at $0.76 \mathrm{~m} \mathrm{~s}^{-1}$ airspeed and $5 \mathrm{~L} \mathrm{~min}^{-1}$ $\mathrm{m}^{-1}$ minimum water flow rate per unit length of the pad in severe conditions, while corrugated cellulose pads of 100 and $150 \mathrm{~mm}$ thickness should be operated at 1.27 and $1.78 \mathrm{~m} \mathrm{~s}^{-1}$ airspeed, respectively, and 6.2 and $9.9 \mathrm{~L} \mathrm{~min}^{-1} \mathrm{~m}^{-1}$ minimum water flow rate per unit length of the pad, respectively.

Malli et al. (2011) investigated the performance of cellulose evaporative cooling pads. Different pad thicknesses were tested for their thermal performance in terms of pressure drop, humidity variation, amount of water evaporated, and saturation efficiency. Specifically, they reported that the pressure drop and the amount of evaporated water increased with frontal air velocity and pad thickness, whereas the saturation efficiency and the relative humidity decreased with increasing air velocity. Franco et al. (2010) discussed the effect of water and airflow rate on the performance of cellulose pads for greenhouse applications. They found that the amount of water evaporated from the cooling pads increased as the difference in the inlet and the outlet air temperature increased. The higher water flow rate of $0.256 \mathrm{~L} \mathrm{~s}^{-1} \mathrm{~m}^{-2}$ was associated to a much higher pressure drop compared to the other water flow rate values at the same air velocity.

The efficiency of the evaporative pad cooling system is necessary for determining the pad efficiency of the saturating inlet air with moisture. Complete (100\%) saturation efficiency means that the incoming air is fully saturated with moisture, causing the relative humidity of the incoming air to increase to $100 \%$. The efficiency of the evaporative pad cooling system is designed to range between 70 and $80 \%$. The cooling efficiency is less than $100 \%$ to prevent the incoming relative humidity from becoming excessive (typically between 75 and 85\%) (Czarick and Fairchild, 2014). An evaporative pad cooling system was evaluated in a broiler house in the Çukurova region (Adana, South Turkey). The cooling efficiency ranged from 69.2 to $72.0 \%$, and the temperature reduction ranged between 4.4 and $7.3^{\circ} \mathrm{C}$ (Dağtekin et al., 2009b). The mean evaporative pad cooling system efficiency was $69.35 \%$, and the cooling effect was $5.19^{\circ} \mathrm{C}$ in August and September under Mediterranean climate conditions inside a laying hen house with a capacity of 15,000 birds (Dağtekin et al., 2009a). A lower water flow rate resulted in the accumulation of minerals, which caused the deterioration in pad characteristics because, water evaporated from the pad surface and left minerals that clogged the pores of pads. This deterioration in pad characteristics causes reductions in the efficiency of the system over time. As the water flow rate of the pad increases, the wavy structure on the surface of the pad (pores) is covered with water, making it smooth and causing a decrease in the size of the total pad surface area. In regions where the pad pores are in close proximity (in small pore pads), excess water reduces the area of the pad surface in contact with the air crossing the pores. As a result, air flows more readily through the pad, and cooling efficiency is much higher (Yildiz et al., 2010). The pad face air velocity should range between 0.5 and $1.5 \mathrm{~m} \mathrm{~s}^{-1}$ (Dağtekin et al., 2011). Karaca et al. (2016) studied the relationship between the cooling effect and the pad water flow rate $\left(2,4\right.$, and $6 \mathrm{~L} \mathrm{~min}^{-1}$ $\mathrm{m}^{-2}$ ) and two different pad air velocities $\left(1.0\right.$ and $\left.1.5 \mathrm{~m} \mathrm{~s}^{-1}\right)$. The cooling effect and saturation efficiency values were the lowest at a water flow rate of $6 \mathrm{~L} \mathrm{~min}^{-1} \mathrm{~m}^{-2}$, but they also were relatively similar at water flow rates of 4 and $2 \mathrm{~L} \mathrm{~min}^{-1} \mathrm{~m}^{-2}$.

This research was based on the assumption that operating evaporative pad cooling systems generally use an unsuitable water flow rate. A low water flow rate leads to the accumulation of minerals on pad surfaces, which deteriorates pad characteristics and reduces the efficacy of the pad cooling system. By contrast, a high pad water flow rate increases air relative humidity inside the housing above $70 \%$, especially when outside air relative humidity is high (ranging from 50 to $60 \%$ ). In this study, the water flow rate was assumed to be an important parameter, because it affects the ability of the pad-fan system to absorb and evaporate water to complete the cooling process. The goals of this study were to: i) evaluate the effect of different water flow rates on evaporative pad cooling system performance; ii) determine the most suitable water flow rate for operating pad fan cooling systems; and iii) maintain a thermally comfortable zone for laying hen production.

\section{Materials and methods}

\section{Materials}

The experimental work was conducted in three commercial laying hen houses in Egypt $\left(31.06^{\circ} \mathrm{N}, 31.16^{\circ} \mathrm{E}\right)$. The experiments were conducted in the relatively hot summer season of 2017.

\section{Laying hen house}

Three identical laying hen houses rectangular in shape were used for the experimental work. The dimensions of the laying hen houses were $50 \mathrm{~m}$ in length, $9 \mathrm{~m}$ in width, and $3.5 \mathrm{~m}$ in height and had a floor surface area of $450 \mathrm{~m}^{2}$ and a volume of $1575 \mathrm{~m}^{3}$. The house had a north-south orientation (Figure 1). The ceiling was made with $0.2 \mathrm{~m}$ of reinforced concrete, and the house walls were made of $12-\mathrm{cm}$ red bricks and were blasted with $5 \mathrm{~cm}$ of cement mortar. The laying hen houses were equipped with a mechanical feeder system (chain feeder system) and a nibble drinking system. 


\section{Laying hens}

Each laying hen house was occupied by a total of 3600, 32week-old Ross birds with masses of $1.85 \mathrm{~kg}$.

\section{Evaporative cooling system}

All houses were equipped with a pad fan evaporative cooling system. The pads were distributed at the end of the eastern and western walls, and the ventilation fans were installed on the southern wall. The evaporative pad cooling system consisted of a pad, a water line supply, a $350 \mathrm{~W}$ water pump, a perforated polyvinyl chloride (10-mm diameter) distribution pipe, a gutter, two storage tanks with a volume of $250 \mathrm{~L}$ each, and a bleed-off line (Figure 2).

Fourteen corrugated cellulose pads, each $0.6 \mathrm{~cm}$ in width and $1.5 \mathrm{~m}$ in height, were used. The total face area of the cooling pads was $13.5 \mathrm{~m}^{2}$ (9 $\mathrm{m}$ in length and $1.5 \mathrm{~m}$ in height); the pads were 15 $\mathrm{cm}$ thick and mounted vertically. Four axial-flow, direct-driven suction fans with a diameter of $140 \mathrm{~cm}$, three phases, and a 42,000 $\mathrm{m}^{3} \mathrm{~h}^{-1}$ discharge were used to provide a maximum mass airflow rate of $56 \mathrm{~kg} \mathrm{~s}^{-1}$ during hot periods under $2.5 \mathrm{~mm}$ of static pressure. Fans were operated by an electric motor with a belt pulley by attaching an electronic tap changer to each of the fan motors, thus making it possible to achieve easily the desired air velocity. The air mass flow rate can be quantified by multiplying the adjusted mean pad face air velocity, air density, length of pad, and pad height.

\section{Methods}

The experiment was conducted in three identical laying hen houses (A, B, and C) with 3600 laying hens in each house. The experiments were conducted to assess the effects of the water flow rate on the evaporative cooling system performance in terms of sat-

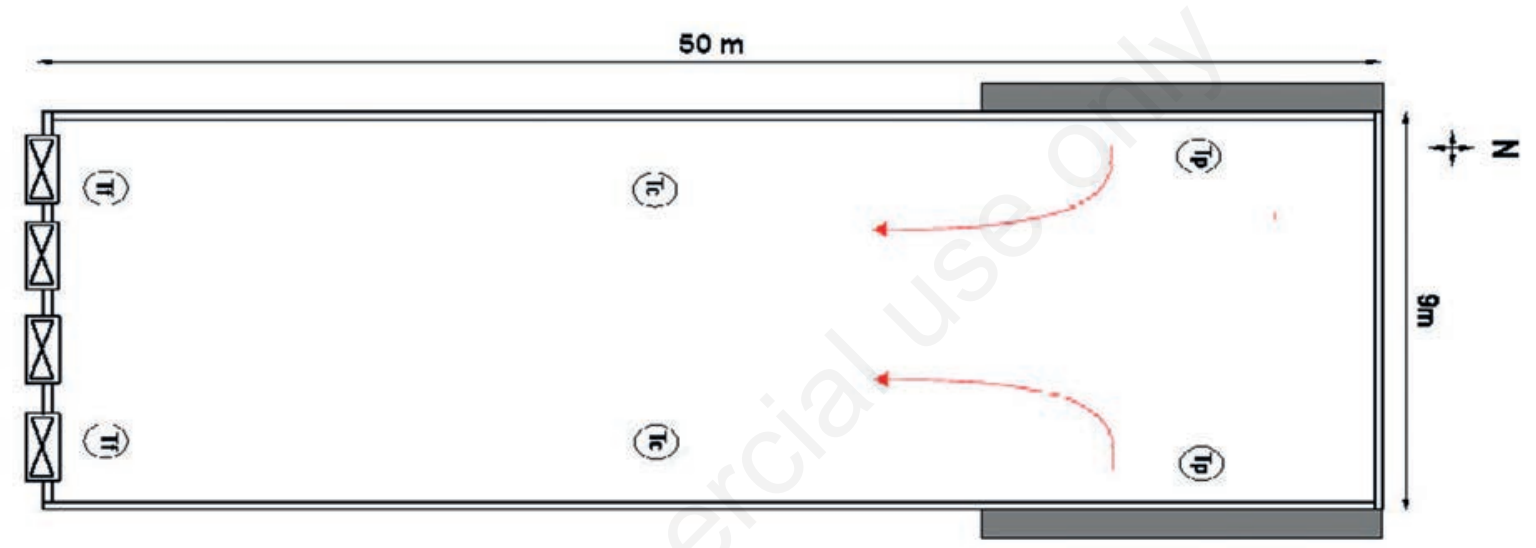

Figure 1. Schematic diagram showing the distribution of temperature sensors inside the laying hen houses.

3

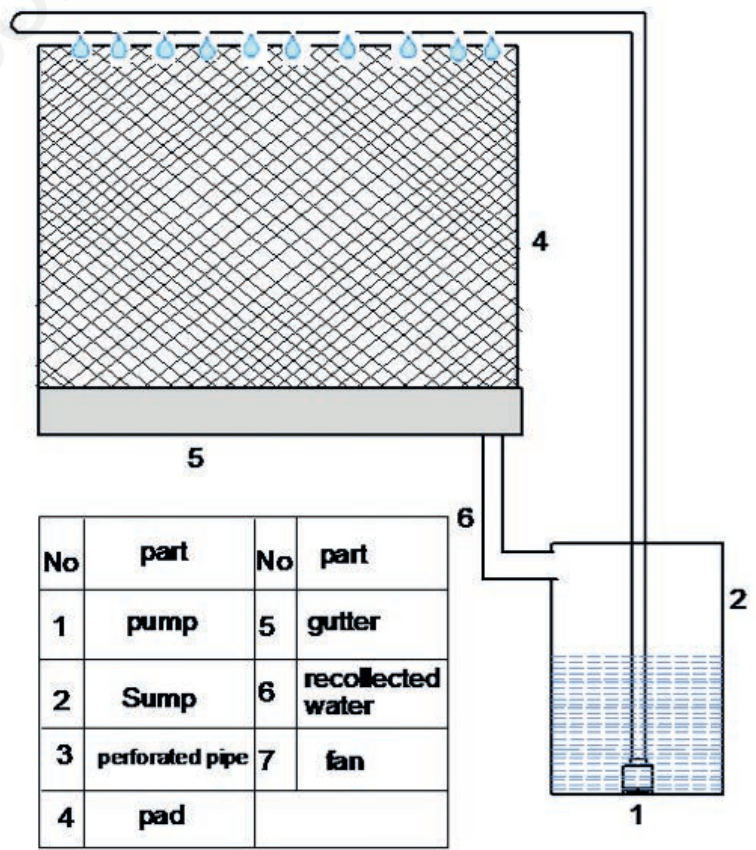

Figure 2. Schematic diagram showing the evaporative pad cooling system. 
uration efficiency, temperature reduction, cooling energy, and water consumption on evaporation. Therefore, the most suitable water flow rate was used for cooling system operation. Three water flow rates were used $\left(4.76,5.56\right.$, and $\left.6.35 \mathrm{~L} \mathrm{~min}^{-1} \mathrm{~m}^{-2}\right)$ from 13 June to 10 July of 2017. The water pump withdrew water from a sump through a filter and then pumped it through a perforated distribution pipe above the pads. A gutter under the pads was used to collect water draining from the pads. The collected water can be recycled as long as salt or minerals do not accumulate on pads. A valve was used to adjust the water flow rate through the distribution pipe. The water flow rate was measured using a measuring cylinder and a chronometer. A Mt 512 E-temperature controller and indicator with temperature control between -50 to $75^{\circ} \mathrm{C}$ was used to read and control the temperature inside the laying hen houses. It has a serial output for communication with the SITRAD program. SITRAD is Full Gauge Controls software for the local module: it must be installed on the computer to which the controllers are connected through a serial converter (32 channels). In other words, it must be installed close to the controllers, and its sheet reader shows the number of sensors and their temperature values. The calibration of the sensor was successfully completed at the beginning of the experiments. The control system was used to control the indoor air temperature at a set point of $28^{\circ} \mathrm{C}$ and was installed at a height of $50 \mathrm{~cm}$ with a differential temperature of $0.1^{\circ} \mathrm{C}$. The sensor of the controller was set at the last third of the house near the ventilation fan. Therefore, if the house temperature increases over $28^{\circ} \mathrm{C}$, the cooling system pump reduces the indoor air temperature to the pre-set points. The thermostat stopped the pump before all of the fans stopped working so that the pad could dry.

\section{Measurements}

\section{Temperature measurements}

Three data-logger devices ( 16 channels) were used for collecting, recording, and reading from the different sensors (LM thermistors with a typical accuracy of $\pm\left(1 / 4^{\circ} \mathrm{C}\right)$ at room temperature and $\pm 3 / 4^{\circ} \mathrm{C}$ over a full -55 to $+150^{\circ} \mathrm{C}$ temperature range) installed at different positions inside and outside the laying hen houses. Dry and wet-bulb temperatures were measured at six different locations along the inside of the laying hen houses, including air temperature at the pads $\left(\mathrm{T}_{\mathrm{pad}}\right)$, the middle of the house $\left(\mathrm{T}_{\text {center }}\right)$, and near the fans $\left(T_{\text {fan }}\right)$. Then, the average temperatures were calculated. Figure 1 shows the locations where the temperature was measured. Two sensors were used to measure dry and wet-bulb temperatures outside the house. Wet-bulb temperature $\left(\mathrm{W}_{\mathrm{b}}\right)$ was measured by thermistors wrapped in wet clothes. The psychometric chart program was used to calculate the relative humidity in front of the pad $\left(R h_{\text {pad }}\right)$, at the centre of the house $\left(\mathrm{Rh}_{\text {center }}\right)$, near the ventilation fans $\left(\mathrm{RH}_{\text {fan }}\right)$, and outside the houses $\left(\mathrm{Rh}_{\text {out }}\right)$ (Figure 1). The data logger was equipped with a keyboard and a monitor. The computer programs Lap Jack and Profilap were employed. The Lap Jack program was used to run the data logger on the computer, and the Profilap program was used to convert the reading from analogue to digital. The time interval for the data recording was 5 minutes, and data were acquired every minute for integrated measurements. All of the sensors and data loggers were calibrated at the beginning of the experiments.

\section{Pad face air velocity}

A digital fan anemometer (model TFA) was used to measure mean pad face air velocity, airflow rate from the axial fans, and mean air velocity in laying hen houses. The anemometer had a range of 0.1 to $30 \mathrm{~m} \mathrm{~s}^{-1}$ and an accuracy of $\pm 5 \%$. Mean pad face air velocity was measured for each house at 30 points across the pad face area. The mean value of the measured points was then calculated. The axial fans were calibrated by measuring the airspeed exiting from the fan outlet at nine different points within the crosssectional area of the fan. Airspeed exiting from the fan outlet was determined by calculating the mean value of nine measurements. The airflow rate at the fan outlet was then calculated by multiplying the mean airspeed by the cross-sectional area of the fan.

\section{Calculation}

\section{Cooling potential (cooling effect)}

The cooling effect can be expressed as temperature reduction and was estimated using Equation (1):

$$
\Delta T=T_{d b, o}-T_{d b, p}
$$

where $\Delta \mathrm{T}$ is the cooling effect, $\mathrm{T}_{\mathrm{db}, \mathrm{o}}$ is the outside air dry-bulb temperature $\left({ }^{\circ} \mathrm{C}\right)$, and $\mathrm{T}_{\mathrm{db}, \mathrm{p}}$ is the dry-bulb temperature $\left({ }^{\circ} \mathrm{C}\right)$ of air just leaving the pad.

The average cooling potential was calculated for each experimental treatment.

\section{Saturation efficiency}

Saturation efficiency (SE) is defined as the ratio between the actual dry-bulb temperature reduction (i.e., cooling effect) and the theoretical maximum at $100 \%$ saturation (ASHRAE, 2005). It is calculated as a percentage from the following Equation (2):

$$
\eta=\frac{\Delta T}{T_{d b, o}-T_{d b, o}} \times 100(\%)
$$

where $\eta$ is the saturation efficiency (\%), $\mathrm{T}_{\mathrm{wb}, \mathrm{o}}$ is the wet-bulb temperature of the outside air entering the pad $\left({ }^{\circ} \mathrm{C}\right)$ (i.e., air temperature at saturation), and $\mathrm{T}_{\mathrm{db}, \mathrm{o}}-\mathrm{T}_{\mathrm{wb}, \mathrm{o}}$ is the wet-bulb depression $\left({ }^{\circ} \mathrm{C}\right)$.

\section{Cooling energy}

The cooling energy is calculated by the temperature difference at the inlet and the outlet according to Equation (3) (Laknizia et al., 2019):

$$
Q=m \times c p \times \Delta T
$$

where $\mathrm{Q}$ is the cooling energy $(\mathrm{kWh}), \mathrm{m}$ is the air mass flow rate $\left(\mathrm{kgs}^{-1}\right)$, and $\mathrm{cp}$ is the specific heat of air $\left(\mathrm{kJ} \mathrm{kg}^{-1} \cdot{ }^{\circ} \mathrm{C}^{-1}\right)$.

$$
\mathrm{m}_{\text {air }}=\rho \times V \times L \times H
$$

where $\rho$ is the air density, $\mathrm{V}$ is the mean pad air velocity $\left(\mathrm{m} \mathrm{s}^{-1}\right), \mathrm{L}$ is the width of the pad cooling $(\mathrm{m})$, and $\mathrm{H}$ is the height of the pad cooling $(\mathrm{m})$. The cooling energy required for water evaporation is a function of time. The Ec required for water evaporation is a function of time $(\mathrm{t})$. The relation $\operatorname{ship} \mathrm{Ec}=\mathrm{f}(\mathrm{t})$ can be identified from experimental data between Ec vs. $\mathrm{t}$ using a definite integral as shown in the following to calculate the area between the best-fit curve and the t-axis, where the lower and upper bounds of the inte- 
gral correspond to the start and end time of operation (in this case, 09:00 to 16:00 h). This area represented the amount of energy required for completing the evaporation process. The formula used to calculate the cooling energy can be written as:

$$
\text { E.C }=\int_{9}^{16} f(x) d x
$$

\section{Water consumption}

Water consumption in the evaporation process was calculated by Equation (5):

$$
\mathrm{m}_{\mathrm{e}}=\mathrm{M} \times\left(\mathrm{w}_{\text {out }}-\mathrm{w}_{\text {in }}\right)
$$

where $\mathrm{m}_{\mathrm{e}}$ is the water consumption $\left(\mathrm{kg} \mathrm{h}^{-1}\right), \mathrm{M}$ the air mass flow rate $\left(\mathrm{kg} \mathrm{h}^{-1}\right)$, $\mathrm{w}_{\text {out }}$ is the humidity ratio of air before pads ( $\mathrm{kg}$ water . $\mathrm{kg}^{-1}$ dry air $)$, and $\mathrm{w}_{\text {in }}$ is the humidity ratio of air after pads $\left(\mathrm{kg}_{\text {water }}\right.$. $\mathrm{kg}^{-1}$ dry air).

\section{Temperature-humidity index}

Temperature-humidity index (THI) values for laying hens were determined for the experimental period using Equation (6) (Gates et al., 1995):

$$
\mathrm{THI}=0.6 \mathrm{~T}_{\mathrm{db}, \mathrm{i}}+0.4 \mathrm{~T}_{\mathrm{wb}, \mathrm{i}}
$$

where THI is the temperature-humidity index $\left({ }^{\circ} \mathrm{C}\right), \mathrm{T}_{\mathrm{db}, \mathrm{i}}$ is the indoor dry-bulb air temperature $\left({ }^{\circ} \mathrm{C}\right)$, and $\mathrm{T}_{\mathrm{wb}, \mathrm{i}}$ is the indoor wetbulb air temperature $\left({ }^{\circ} \mathrm{C}\right)$. The THI equation was used to assess the production of laying hens in response to heat stress. A threshold temperature of $28^{\circ} \mathrm{C}$ was used for the temperature-humidity index for laying hens (Gates et al., 1995).

\section{Results and discussion}

\section{Effect of water flow rate on indoor air temperature and relative humidity}

Figure 3 shows the weekly mean hourly indoor air temperature for 7 hours during daytime, when the pad evaporative cooling system was in operation. These indoor temperatures were compared with the outdoor air temperature from June 13 to July 10, 2017. The thermal variation was observed along the house, because of the long distance of the airstream (50 $\mathrm{m}$ in length) and the sensible heat emitted from the hens. The temperature gradually increased from the pad $\left(\mathrm{T}_{\mathrm{pad}}\right)$ to the ventilation fans $\left(\mathrm{T}_{\mathrm{fan}}\right)$ in all treatments. The effect of outdoor conditions on the indoor conditions at three water flow rates $\left(4.76,5.65\right.$, and $\left.6.35 \mathrm{~L} \mathrm{~min}^{-1} \mathrm{~m}^{-2}\right)$ was investigated. The temperature difference between the pad located at the beginning of the house and the pad located at the end of the house near the fan inside the house varied from 3.5 to $5.15^{\circ} \mathrm{C}(4.76 \mathrm{~L}$ $\mathrm{min}^{-1} \mathrm{~m}^{-2}$ treatment $), 3.9$ to $4.7^{\circ} \mathrm{C}\left(5.65 \mathrm{~L} \mathrm{~min}^{-1} \mathrm{~m}^{-2}\right.$ treatment $)$, and 3.8 to $4.75^{\circ} \mathrm{C}\left(6.35 \mathrm{~L} \mathrm{~min}^{-1} \mathrm{~m}^{-2}\right.$ treatment $)$.

Figure 4 indicates the weekly mean hourly relative humidity (RH) in front of the pads, at the centre of the house; outside the laying hen houses, and in front of the fans. Indoor relative humidity was higher than outdoor relative humidity. Indoor relative humidity was high in front of the pads and decreased gradually towards the end of the house near the extraction fans in all treatments. The weekly mean hourly indoor relative humidity ranged from 60.7 to $82 \%$ at a $4.76 \mathrm{~L} \mathrm{~min}^{-1} \mathrm{~m}^{-2}$ flow rate; 63.5 to $79 \%$ at a $5.65 \mathrm{~L} \mathrm{~min}^{-}$ ${ }^{1} \mathrm{~m}^{-2}$ flow rate, and 61.5 to $80.6 \%$ at a $6.35 \mathrm{~L} \mathrm{~min}^{-1} \mathrm{~m}^{-2}$ flow rate.

\section{The performance of the pad cooling system}

Figure 5 shows the weekly mean hourly values of saturation efficiency and cooling effect under different water flow rates. The maximum saturation efficiency was observed at noon or in the afternoon, when the difference between the outside and inside air temperature increased. At a flow rate of $4.76 \mathrm{~L} \mathrm{~min}^{-1} \mathrm{~m}^{-2}$, the weekly mean daily values for saturation efficiency were $72.27 \%$ (June 13-19); $76.99 \%$ (June 20-26), 66.44\% (June 27-July 3), and 79.29\% (July 4-10); weekly mean daily cooling effect values were $4.88^{\circ} \mathrm{C}$ (June $\left.13-19\right), 5.48^{\circ} \mathrm{C}$ (June 20-26), $4.76^{\circ} \mathrm{C}$ (June 27-July 3), and $5.37^{\circ} \mathrm{C}$ (July 4-10). At a flow rate of $5.56 \mathrm{~L} \mathrm{~min}^{-1} \mathrm{~m}^{-2}$, the weekly mean daily values for saturation efficiency were 70.59\% (June 13-19), 70.91\% (June 20-26), $68.71 \%$ (June 27-July 3), and 74.94\% (July 4-10); weekly mean daily cooling effect values were $4.76^{\circ} \mathrm{C}$ (June $13-19$ ), $5.10^{\circ} \mathrm{C}$ (June 20-26), $4.91^{\circ} \mathrm{C}$ (June $27-J u l y 3$ ), and $5.06^{\circ} \mathrm{C}$ (July 4-10). At a flow rate of 6.35 $\mathrm{L} \mathrm{min}^{-1} \mathrm{~m}^{-2}$, the weekly mean daily values for saturation efficiency were $75.80 \%$ (June 13-19), 65.05\% (June 20-26), 66.07\% (June 27July 3 ), and $75.59 \%$ (July 4-10); the weekly mean daily cooling effect values were 5.08 (June 13-19), 4.65 (June 20-26), 4.70 (June 27-July 3 ), and $5.13^{\circ} \mathrm{C}$ (July 4-10). A flow rate of $4.76 \mathrm{~L} \mathrm{~min}^{-1} \mathrm{~m}^{-2}$ resulted in higher cooling efficiency values relative to the other treatments except for the June 13-19 period, when a flow rate of $6.35 \mathrm{~L} \mathrm{~min}^{-1} \mathrm{~m}^{-2}$ resulted in the highest cooling efficiency. From 27 June to 3 July, the $5.56 \mathrm{~L}$ $\mathrm{min}^{-1} \mathrm{~m}^{-2}$ flow rate resulted in higher cooling efficiency compared with the other treatments, which may be related to the outside weather conditions. The weekly mean values for saturation efficiency during the experimental period were $73.75 \%, 71.3 \%$, and $70.63 \%$ for water flow rates of $4.76,5.56$, and $6.35 \mathrm{~L} \mathrm{~min}^{-1} \mathrm{~m}^{-2}$, respectively. These findings are similar to those of Karaca et al. (2016). Three multiple regression equations were developed to describe the relationship between SE and outdoor temperature $\left(\mathrm{T}_{\mathrm{db}, \mathrm{o}}\right)$, outdoor relative humidity $\left(\mathrm{RH}_{0}\right)$, and temperature of the pad $\left(\mathrm{T}_{\mathrm{p}}\right)$ for the various water flow rates. The multiple regression analysis revealed that the saturation efficiency for the three tested water flow rates was strongly affected by outdoor temperature, outdoor relative humidity, and pad temperature. The multiple regression equations obtained were as follows:

$$
\begin{array}{ll}
\operatorname{SE}(4.76)=12.6 \mathrm{~T}_{\mathrm{dbo}}+1.77 \mathrm{RH}_{\mathrm{o}}-14.48 \mathrm{~T}_{\mathrm{p}}-42.34 & \mathrm{R}^{2}=0.9927 \\
\operatorname{SE}(5.56)=12.54 \mathrm{~T}_{\mathrm{dbo}}+1.75 \mathrm{RH}_{\mathrm{o}}-14.11 \mathrm{~T}_{\mathrm{p}}-48.78 & \mathrm{R}^{2}=0.9934 \\
\operatorname{SE}(6.35)=8.69 \mathrm{~T}_{\mathrm{dbo}}+1.90 \mathrm{RH}_{\mathrm{o}}-9.29 \mathrm{~T}_{\mathrm{p}}-65.5 & \mathrm{R}^{2}=0.7103
\end{array}
$$

The combined correlation coefficients ( $r$ ) for these parameters together were $0.9963,0.9971$, and 0.8427 for the $4.76,5.56$, and 6.35 $\mathrm{L} \mathrm{min}^{-1} \mathrm{~m}^{-2}$ water flow rates, respectively.

\section{Cooling energy}

Figure 6 shows the cooling energy from 09:00 to 16:00 h. The equations corresponding to the best fit for the relationship between cooling energy and time are also shown (Figure 6).

Less energy was absorbed when the water flow rate increased in all treatments, except from June 27-July 3 at a flow rate of $5.56 \mathrm{~L} \mathrm{~min}^{-1} \mathrm{~m}^{-2}$ and from July 4-10 at a flow rate of $6.35 \mathrm{~L} \mathrm{~min}^{-1} \mathrm{~m}^{-2}$. These previous observations indicate that the cooling energy required for water evaporation increased as the area under the curve increased. Consequently, 
the ability of an evaporative cooling system to reduce the outside air temperature increased as well.

The mean area under the curve decreased as the water flow rate increased. The $4.76 \mathrm{~L} \mathrm{~min}^{-1} \mathrm{~m}^{-2}$ water flow rate had the highest area under the curve (486.01 units or $69.11 \mathrm{~kW} . \mathrm{h}$ ) (Figure 7). The $4.76 \mathrm{~L}$ $\mathrm{min}^{-1} \mathrm{~m}^{-2}$ water flow rate also had the highest cooling energy compared with the other water flow rates.

\section{Temperature humidity index}

High temperatures coupled with high humidity impose severe stress on birds and lead to lower performance. However, measurements of air temperatures inside the houses or air relative humidity in isolation are not sufficient to assess heat stress. Consequently, records tabulated by Gates et al. (1995) on adapted THI for laying hens should be considered, when assessing heat stress. THI values should range between 21.1 to $28^{\circ} \mathrm{C}$. THI values over $28^{\circ} \mathrm{C}$ place birds under heat stress and could reduce performance. Heat stress reduces the egg production of laying hens. THI values for different days in each treatment were roughly the same; the hourly THI for every treatment was calculated and is shown in Table 1. Hourly THI values at various water flow rates (25.24-27.78 $\mathrm{C})$ indicated that the birds did not experience heat stress. All treatments showed the same pattern. The THI values calculated inside the laying hen houses and the mean $\mathrm{THI}$ were $26.94^{\circ} \mathrm{C}, 26.79^{\circ} \mathrm{C}$, and $26.83^{\circ} \mathrm{C}$ for water flow rates of $4.76,5.56$, and $6.35 \mathrm{~L} \mathrm{~min}^{-1} \mathrm{~m}^{-2}$, respectively. The THI equation was used to examine the relationships between indoor air temperature $\left(\mathrm{T}_{\mathrm{db}, \mathrm{i}}\right)$ and indoor relative humidity $\left(\mathrm{RH}_{\mathrm{i}}\right)$ for the three different water flow rates. The multiple regression analysis revealed that the THI at various water flow rates was strongly related to indoor air temperature and relative humidity. The multiple regression equations obtained were as follows:

$$
\begin{array}{ll}
\operatorname{THI}(4.76)=0.8133 \mathrm{~T}_{\mathrm{dbi}}+0.028 \mathrm{RH}_{\mathrm{i}}-0.28 & \mathrm{R}^{2}=0.8854 \\
\operatorname{THI}(5.65)=0.7709 \mathrm{~T}_{\mathrm{dbi}}+0.026 \mathrm{RH}_{\mathrm{i}}+0.95 & \mathrm{R}^{2}=0.8074 \\
\operatorname{THI}(6.35)=0.8644 \mathrm{~T}_{\mathrm{dbi}}+0.010 \mathrm{RH}_{\mathrm{i}}-0.40 & \mathrm{R}^{2}=0.8931
\end{array}
$$

The combined correlation coefficients for the effects of these parameters were $0.9409,0.8985$, and 0.9450 for water flow rates of $4.76,5.56$, and $6.35 \mathrm{~L} \mathrm{~min}^{-1} \mathrm{~m}^{-2}$, respectively.

\section{Pad water consumption}

The amount of water that the evaporative pad cooling system used for heat reduction was mainly dependent on three factors: outdoor temperature, relative humidity, and mass airflow rate through the pads. Maximum evaporation was achieved when pads were not continuously wet. The water flow rate should be adjusted to provide sufficient pad moisture, maximize water evaporation, and prevent increases in humidity. If the water added to the house environment exceeds the capacity of the ventilation system to decrease humidity, several problems can arise, including wet litter, high relative humidity, and high effective temperatures. Low humidity facilitates evaporation and, therefore, cooling.

Figure 8 shows the mean hourly pad water use during the experimental period under different water flow rates. At the water flow rate of $4.76 \mathrm{~L} \mathrm{~min}^{-1} \mathrm{~m}^{-2}$, the range of water consumed by pads was between 337.97 (09:00) and 498.6 $\mathrm{L} \mathrm{h}^{-1}$ (14:00 h).

Pad water consumption ranged from 302.2 (13:00) and $456.4 \mathrm{~L}$ $\mathrm{h}^{-1}(14: 00 \mathrm{~h})$ at a water flow rate of $5.56 \mathrm{~L} \mathrm{~min}^{-1} \mathrm{~m}^{-2}$. At $6.35 \mathrm{~L}$ $\mathrm{min}^{-1} \mathrm{~m}^{-2}$, water use ranged between 388.9 (10:00) and $490.6 \mathrm{~L} \mathrm{~h}^{-1}$ $(15: 00 \mathrm{~h})$. Mean hourly pad water use during the experimental period was higher at a water flow rate of $6.35 \mathrm{~L} \mathrm{~min}^{-1} \mathrm{~m}^{-2}(431.3$ $\mathrm{L} \mathrm{h}^{-1}$ ) compared with the other treatments.

Based on the data in Figure 8, the following three multiple regression equations were derived to describe the relationship between pad water use and outdoor dry-bulb temperature $\left(\mathrm{T}_{\mathrm{db}, o}\right)$, outdoor relative humidity $\left(\mathrm{RH}_{0}\right)$, pad temperature $\left(\mathrm{T}_{\mathrm{p}}\right)$, and relative humidity in front of the pad $\left(\mathrm{RH}_{\mathrm{p}}\right)$ for various tested water flow rates. The multiple regression analysis revealed that the pad water use for the three water flow rates was strongly affected by outdoor temperature, outdoor relative humidity, pad temperature, and relative humidity. The multiple regression equations obtained were the following:

$$
\begin{array}{lll}
\mathrm{m}_{\mathrm{e}}(4.76)=377.5 \mathrm{~T}_{\mathrm{p}}+62.45 \mathrm{RH}_{\mathrm{p}}-331.3 \mathrm{~T}_{\mathrm{dbo}}-80.63 \mathrm{RH}_{\mathrm{o}}+94.69 & \mathrm{R}^{2}=0.6382 \\
\mathrm{~m}_{\mathrm{e}}(5.56)=187.96 \mathrm{~T}_{\mathrm{p}}+39.00 \mathrm{RH}_{\mathrm{p}}-180.3 \mathrm{~T}_{\mathrm{dbo}}-51.58 \mathrm{RH}_{\mathrm{o}}+677.45 & \mathrm{R}^{2}=0.7422 \\
\mathrm{~m}_{\mathrm{e}}(6.35)=219.68 \mathrm{~T}_{\mathrm{p}}+42.88 \mathrm{RH}_{\mathrm{p}}-199.55 \mathrm{~T}_{\mathrm{dbo}}-54.70 \mathrm{RH}_{\mathrm{o}}+308.32 & \mathrm{R}^{2}=0.8880
\end{array}
$$

The combined correlation coefficients for these parameters were $0.7988,0.8615$, and 0.9423 for water flow rates of 4.76, 5.56, and $6.35 \mathrm{~L} \mathrm{~min}^{-1} \mathrm{~m}^{-2}$, respectively.

Table 1. Mean temperature-humidity index under different water flow rates.

\begin{tabular}{lccc} 
Time & & Temperature-humidity index $\left({ }^{\circ} \mathrm{C}\right)$ & $6.35\left(\mathrm{~L} \mathrm{~min}^{-1} \mathrm{~m}^{-2}\right)$ \\
\hline 09:00 & $\mathbf{5 . 7 6}\left(\mathrm{L} \mathrm{min}^{-1} \mathrm{~m}^{-2}\right)$ & 25.24 & 25.28 \\
10:00 & 25.34 & 26.1 & 26.24 \\
\hline $11: 00$ & 26.24 & 26.42 & 26.46 \\
$12: 00$ & 27.4 & 26.98 & 26.88 \\
\hline $13: 00$ & 26.86 & 26.98 & 27.2 \\
$14: 00$ & 27.2 & 27.62 & 27.66 \\
\hline $15: 00$ & 27.56 & 27.78 & 27.74 \\
$16: 00$ & 27.76 & 27.18 & 27.12 \\
\hline Mean & 27.12 & 26.79 & 26.83 \\
\hline
\end{tabular}



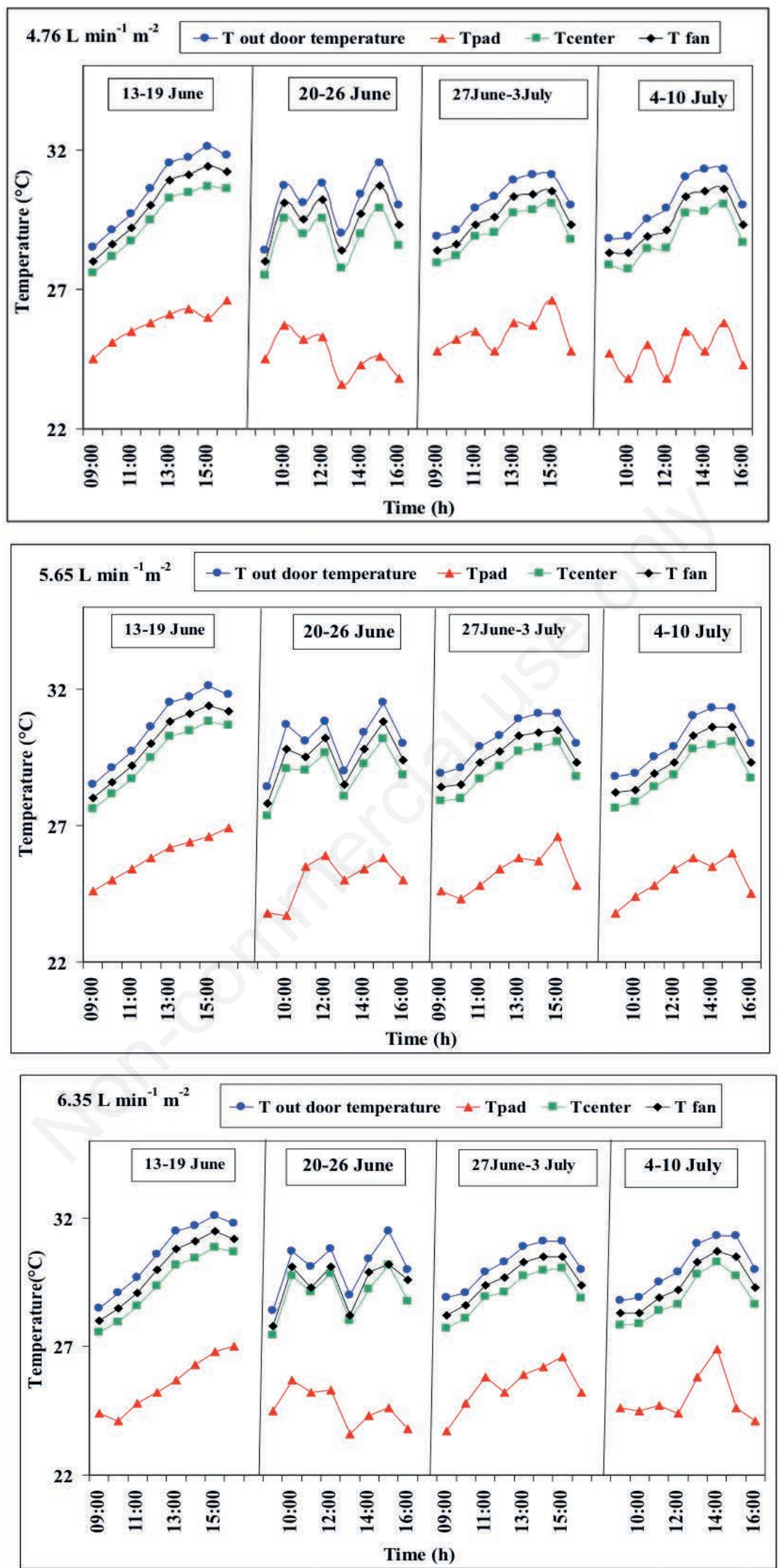

Figure 3. Indoor and outdoor air temperatures under different water flow rates from June 13 to July 10, 2017. 

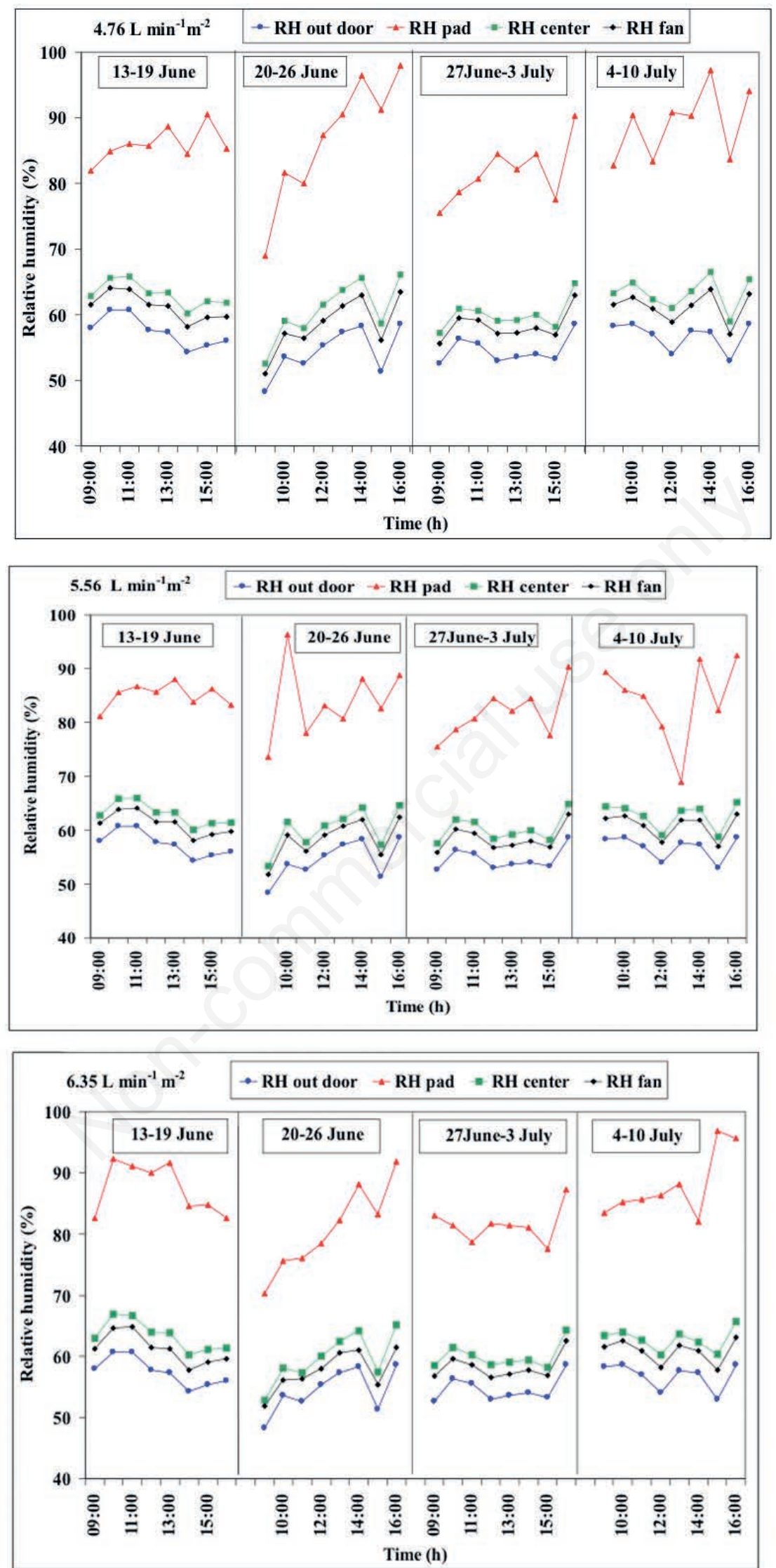

Figure 4. Indoor and outdoor air relative humidity (RH) under different water flow rates from June 13 to July 10, 2017. 

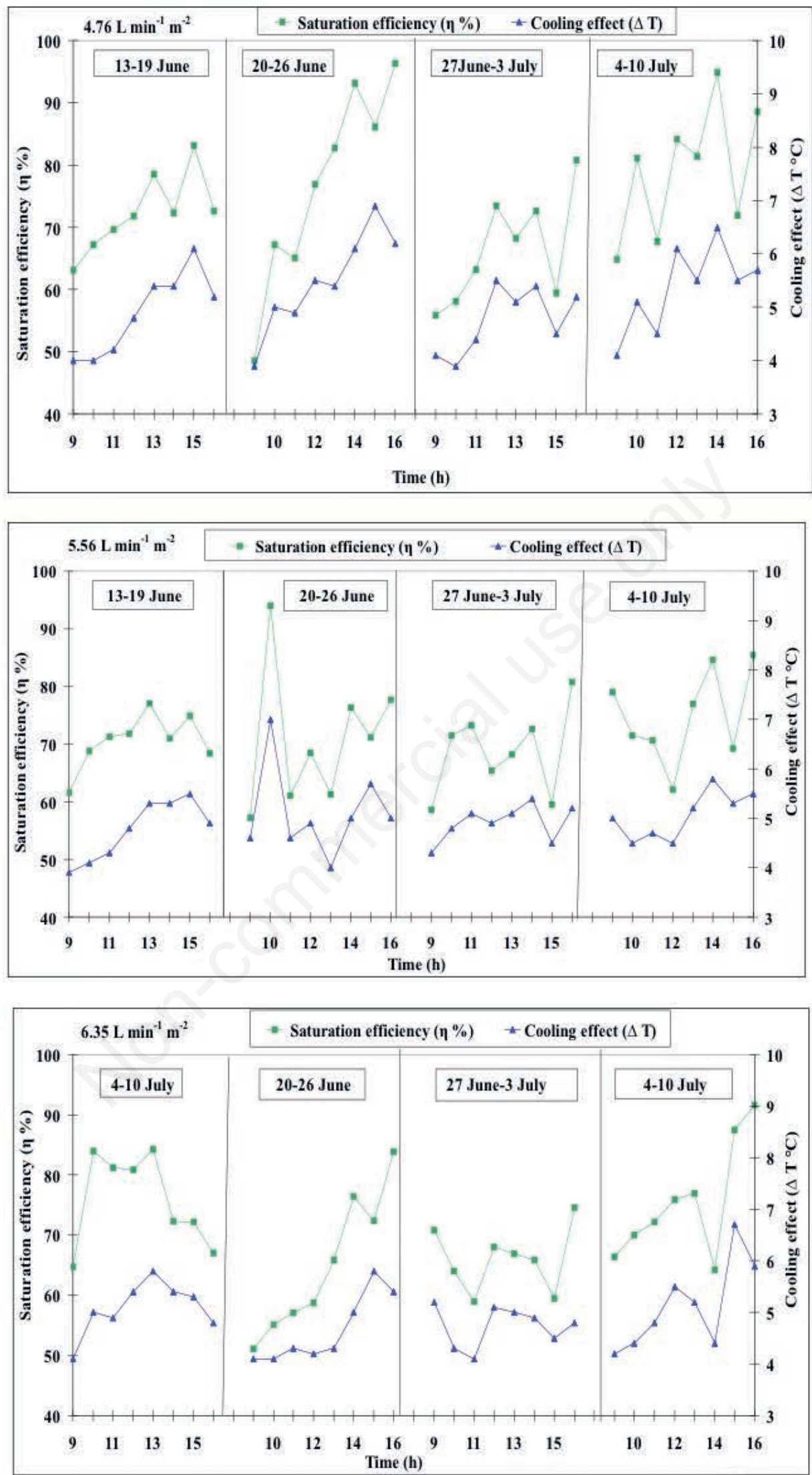

Figure 5. Performance of the evaporative cooling system using different water flow rates from June 13 to July 10, 2017. 


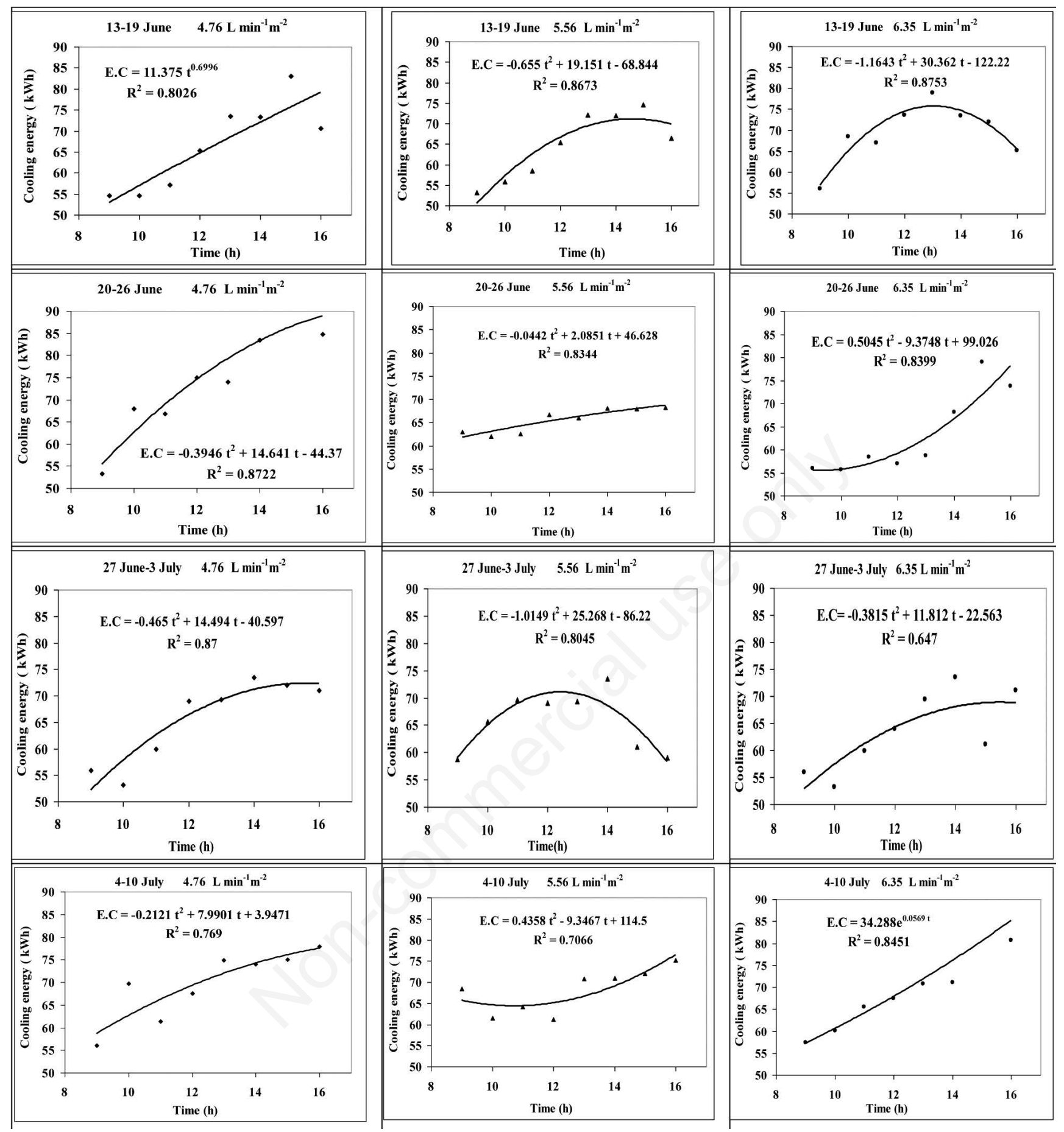

Figure 6. Cooling energy under different pad water flow rates from June 13 to July 10, 2017.

\section{Conclusions}

An evaporative cooling pad fan system was used to reduce heat stress inside three laying hen houses using three different water flow rates from 13 June to 10 July 2017. The main results of the experiment can be summarized as follows: i) all treatments of the evaporative pad cooling system maintained the indoor air temperature within the thermoneutral zone; ii) the daily average indoor air relative humidity during the experimental period was $73.8 \%$, $72.6 \%$, and $72.9 \%$ for water flow rates of $4.76,5.56$, and $6.35 \mathrm{~L}$ $\min ^{-1} \mathrm{~m}^{-2}$, respectively; iii) the mean evaporative pad cooling efficiency during the experimental period was $73.75 \%, 71.3 \%$, and $70.63 \%$ for water flow rates of $4.76,5.56$, and $6.35 \mathrm{~L} \mathrm{~min}^{-1} \mathrm{~m}^{-2}$, respectively; iv) the $4.76 \mathrm{~L} \mathrm{~min}^{-1} \mathrm{~m}^{-2}$ water flow rate was associated with the highest cooling effect; v) the highest cooling energy was recorded for the $4.76 \mathrm{~L} \mathrm{~min}^{-1} \mathrm{~m}^{-2}$ water flow rate; vi) the THI was always below $27.78^{\circ} \mathrm{C}$ in all treatments, which means that laying hens did not experience heat stress during egg production; vii) the mean pad water use increased by $3.55 \%$ at a water flow rate of $6.35 \mathrm{~L} \mathrm{~min}^{-1} \mathrm{~m}^{-2}$ compared with $4.76 \mathrm{~L} \mathrm{~min}^{-1} \mathrm{~m}^{-2}$ and by $11.7 \%$ 


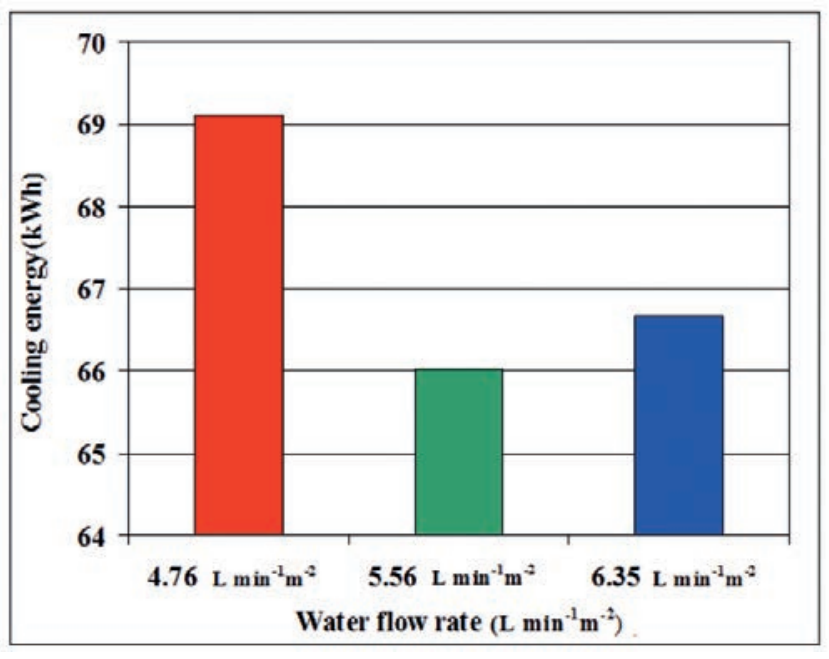

Figure 7. Cooling energy under different water flow rates from June 13 to July 10, 2017.

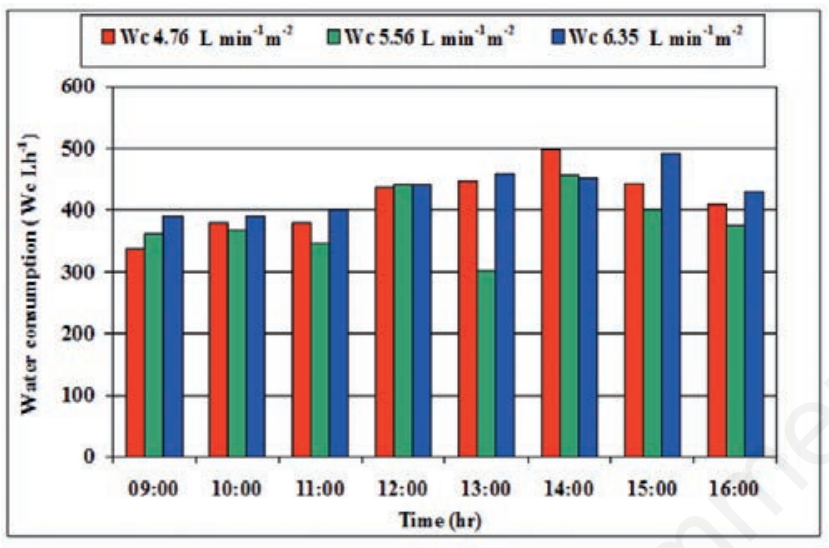

Figure 8. Water consumed under different water flow rates.

compared with $5.56 \mathrm{~L} \mathrm{~min}^{-1} \mathrm{~m}^{-2}$; viii) the optimum water flow rate for the operating pad cooling system was $4.76 \mathrm{~L} \mathrm{~min}^{-1} \mathrm{~m}^{-2}$.

\section{References}

ASABE. 2008. EP566.1: Guidelines for selection of energy-efficient agricultural ventilation fans. In: ASABE Standards. ASABE, St. Joseph, MI, USA.

ASHRAE. 2005. Handbook of fundamentals. American Society of Heating, Refrigerating, and Air Conditioning Engineers, Atlanta, GA, USA.

ANSI/ASABE. 2008. EP406.4: Heating, Ventilating, and Cooling Greenhouses. In: ASSI/ASABE Standards. ASABE, St. Joseph, MI, USA.

Charles D.R. 2002. Responses to the thermal environment. In: Charles D.R. (Ed.), Poultry environment problems, A guide to solutions. Nottingham University Press, Nottingham, UK, pp:1-6.

Czarick M., Fairchild B.D. 2014. Evaporative cooling pad design spreadsheet, poultry housing tips. University of Georgia, College of Agricultural and Environmental Sciences, Cooperative Extension Service.
Dağtekin M., Karaca C., Yıldız Y., Başçetinçelik A., Paydak Ö. 2011. The effects of air velocity on the performance of pad evaporative cooling systems. Afr. J. Agric. Res. 6:1813-22.

Dağtekin M., Karaca C., Yıldız Y. 2009a. Long axis heat distribution in a tunnel-ventilated broiler house equipped with an evaporative pad cooling system. Anim. Prod. Sci. 49:1125-31.

Dağtekin M., Karaca C., Yıldız Y. 2009b. Performance characteristics of a pad evaporative cooling system in a broiler house in a Mediterranean climate. Biosyst. Eng. 103:100-4.

Dzivama A.U., Bindir U.B., Aboaba F.O. 1999. Evaluation of pad materials in the construction of active evaporative cooler for storage of fruits and vegetables in arid environments. AMA-Agr. Mech. Asia Af. 30:51-5.

Ebeid T.A., Suzuki T., Sugiyama T. 2012. High-temperature influences eggshell quality and calbindin-D28k localization of eggshell gland and all intestinal segments of laying hens. Poult. Sci. 91:2282-322.

Estrada-Pareja M.M., Marquez-Girón S.M., Restrepo Betancur L.F. 2007. Effect of temperature and relative humidity on the productive behavior and the transfer of heat in broilers. Rev. Colomb. Cienc. Pec. 20:288-303.

FAO, 2020. Statistics Division. Poultry production. Available from: http://www.fao.org/faostat/en/\#data/QL

Fairchild B.D. 2012. Environmental factors to control when brooding chicks. University of Georgia Cooperative Extension Service, Colleges of Agricultural and Environmental Sciences. Techn. Bull. 1287:26-34.

Franco A., Valera D.L., Madneno A., Pena A. 2010. Influence of water and air-flow on the performance of cellulose evaporative cooling pads used in Mediterranean greenhouses. T. ASABE. 52:565-76.

Gates R.S., Zhang H., Colliver G., Overhults D.G. 1995. Regional variation temperature-humidity index for poultry housing. T. ASAE. 38:197-205.

Gunhan T., Demir V., Yagcioglu A.K. 2007. Evaluation of the suitability of some local materials as cooling pads. Biosyst. Eng. 96:369-77.

Karaca C., Yıldız Y., Dağtekin M., Gümüş Z. 2016. Effect of water flow rate on cooling effectiveness and air temperature change in evaporative cooling pad systems. Environ. Eng. Manag. J. 15:827-33.

Laknizia A., Mahdaouic M., Abdellah A., Anounea K., Bakhouyab M., Ezbakhed H. 2019. Performance analysis and optimal parameters of a direct evaporative pad cooling system under the climate conditions of Morocco. Case Stud. Therm. Eng. 13:100362.

Malli A., Seyf H.R., Layeghi M., Sharifian S., Behravesh H. 2011. Investigating the performance of cellulose evaporative cooling pads. Energ. Convers. Manage. 52:2596-603.

Nelson P.V. 2006. Greenhouse operation and management. 4th ed. Prentice Hall, NJ, USA.

Porumb B., Unguresan P., Tutunaru L.F., Serbanod A., Balan M. 2016. A review of indirect evaporative technology. Energy Proced. 85:461-71.

Star L., Juul-Madsen H.R., Decuypere E., Nieuwland M.G., de Vries Reilingh G., van den Brand H., Kemp B., Parmentier H.K. 2009. Effect of early life thermal conditioning and immune challenge on thermotolerance and humoral immune competence in adult laying hens. Poult. Sci. 88:2253-61.

Xin H., Gates R.S., Green A.R., Mitloehner F.M., Moore Jr P.A., Wathes C.M. 2011. Environmental impacts and sustainability of egg production systems. Poult. Sci. 90:263-77.

Yıldız Y., Karaca C., Dağtekin M. 2010. Environmental control in livestock shelters: Ventilation, heating, cooling and illumination. Hasad Yayıncılık, Ltd., Şti., P.K. 35, Ümraniye-3470-İstanbul [in Turkish].

You Y. 2005. Research on the effects of hen house environment control on production performance, Ph.D. Thesis, College of Engineering, China Agricultural University, Beijing, China. 